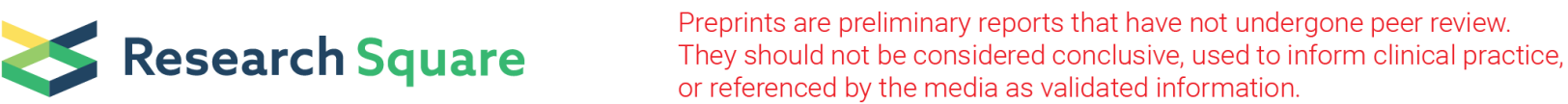

\section{Tailoring Pullulanase PuIAR from Anoxybacillus sp. AR-29 for Enhanced Catalytic Performance by A Structure-Guided Consensus Approach}

\section{Shu-Fang Li}

Zhejiang University of Technology

\section{Shen-Yuan Xu}

Zhejiang University of Technology

Ya-Jun Wang ( $\nabla$ wangyj@zjut.edu.cn )

Zhejiang University of Technology https://orcid.org/0000-0002-2284-0882

\section{Yu-Guo Zheng}

Zhejiang University of Technology

\section{Research Article}

Keywords: pullulanase, structure-guided consensus approach, site-directed mutagenesis, catalytic pocket, stability, catalytic efficiency.

Posted Date: January 6th, 2022

DOI: https://doi.org/10.21203/rs.3.rs-1189094/v1

License: (c) (i) This work is licensed under a Creative Commons Attribution 4.0 International License. Read Full License 


\section{Abstract}

Pullulanase is a well-known debranching enzyme that can specially hydrolyze a-1,6-glycosidic linkages in starch and oligosaccharides, however, it suffers from low stability and catalytic efficiency under industrial conditions. In the present study, four sites (A365, V401, H499, and T504) lining the catalytic pocket of Anoxybacillus sp. AR-29 pullulanase PulAR were selected for site-directed mutagenesis (SDM) by using a structure-guided consensus approach. Four beneficial mutants (PulAR-A365V, PulAR-V401C, PulARA365/V401C, PulAR-A365V/V401C/T504V, and PulAR-A365V/V401C/T504V/H499A) were created, which showed enhanced thermostability, pH stability, and catalytic efficiency. Among them, the quadruple mutant PulAR-A365V/V401C/T504V/H499A displayed 6.6- and 9.6-fold higher catalytic efficiency toward pullulan at $60{ }^{\circ} \mathrm{C}, \mathrm{pH} 5.0$ and 6.0 , respectively. In addition, its thermostabilities at $60^{\circ} \mathrm{C}$ and $65{ }^{\circ} \mathrm{C}$ were improved by 2.6- and 3.1-fold, respectively, compared to those of the wild-type (WT). Meanwhile, its pH stabilities at pH 4.5 and 5.0 were 1.6- and 1.8-fold higher than those of WT, respectively. In summary, the catalytic performance of PuIAR was significantly enhanced via rational engineering by a structure-guided consensus approach. The resultant quadruple mutant PulAR-A365V/V401C/T504V/H499A demonstrated potential applications in the starch industry.

\section{Introduction}

Starch transformation can be accomplished by using an enzymatic process that involves two primary steps: liquefaction and saccharification (Hii et al. 2012). Generally, the saccharification is conducted at $60{ }^{\circ} \mathrm{C}$ and $\mathrm{pH} 4.5-5.5$ for $48-60 \mathrm{~h}$, via pullulanase in combination with $\beta$-amylase or glucoamylase, producing maltose syrup and glucose syrup. Pullulanase [EC 3.2.1.41] is a debranching enzyme that can specifically cleave a-1,6-glycosidic linkages in pullulan, starch, amylopectin, glycogen, and related oligosaccharides (Bertoldo and Antranikian 2002). Addition of pullulanase would reduce the amount of glucoamylase or $\beta$-amylase used in the saccharification step and improve substrate concentration and conversion (Duan et al. 2013). High-purity maltose syrup is a low-calorie, low-sweetness sugar that is being widely used in the food, medicine, and cosmetic industries (Bertoldo et al. 1999), in which the content of maltose is above $60 \%$. In recent years, enzymatic preparation of maltose syrups has drawn rising interest for its mild reaction condition, high selectivity, and high catalytic efficiency (Lin et al. 2013). In combination with $\beta$-amylase and/or maltase, pullulanase can raise starch hydrolysis efficiency to highpurity maltose syrup and reduce production cost (Masahiro et al. 1992).

Pullulanases are divided into type I pullulanase and type II pullulanase based on substrate specificity and reaction products. Type II pullulanase hydrolyzes both a-1,6-glycosidic linkages and a-1,4-glycosidic linkages(Kang et al. 2011; Li et al. 2012; Pang et al. 2019). Compared with type II pullulanase, type I pullulanase specifically hydrolyzes a-1,6-glycosidic linkages in pullulan and other polysaccharides, forming maltotriose and linear oligomers. In recent years, a few type I pullulanases from Fervidobacterium nodosum Rt17-B1(Yang et al. 2020), Bacillus methanolicus PB1 (Zhang et al. 2020), Geobacillus thermocatenulatus DSMZ73010 (Li et al. 2018), Bacillus megaterium W1210 (Yang et al. 2017), Anoxybacillus sp. SK3-4 (Kahar et al. 2016) and Paenibacillus polymyxa Nws-pp2 (Wei et al. 2015) 
have been cloned and characterized. However, most of the reported type I pullulanases exhibit neutral or basic $\mathrm{pH}$ optimum, and their stabilities under acidic or thermophilic conditions are usually poor.

Protein engineering is an efficient way to obtain the desirable enzyme (Böttcher and Bornscheuer 2010). As reported previously, many reports focus on enhancing the thermostability or catalytic efficiency of the type I pullulanases. For example, Duan et al. successfully improved the thermostability and catalytic efficiency of a Type I pullulanase from Bacillus deramificans by site-directed mutagenesis (SDM) (Duan et al. 2013). In a recent example, $\mathrm{Bi}$ and coworkers employed a computer-aided method to improve the thermostability of the thermophilic pullulanase from Bacillus thermoleovorans by raising $T_{m} 3.8^{\circ} \mathrm{C}$ (Bi et al. 2020). Up to date, only a limited number of reports on improving acidic adaptation or acid stability of pullulanase are available (Wang et al. 2017; Zeng et al. 2019). Chen and coworkers improved the acidic adaptation of Bacillus acidopullulyticus pullulanase by altering hydrogen bonds connected to catalytic residues, shifting its optimum pH from 5.0 to 4.0 at the expense of activity (Chen et al. 2019). Therefore, it is still needed to dig out the pullulanase with high catalytic efficiency and stability under thermophilic and acidic conditions.

In this study, we identified a novel pullulanase from Anoxybacillus sp. AR-29 (PulAR). Four residues A365, V401, H499, and T504 lining the catalytic pocket were identified as critical for the thermostability and acid resistance by a structure-guided consensus approach. The catalytic performance of PulAR under thermophilic and acidic conditions was enhanced by SDM. In addition, structural analysis and MD simulations were performed to elucidate their roles.

\section{Materials And Methods}

\subsection{Bacterial strains, plasmids, and enzyme}

Anoxybacillus sp. AR-29 was isolated and stored in our laboratory. The PulAR gene (GenBank accession number KY273924.1) was cloned from Anoxybacillus sp. AR-29. We constructed the pET-32a (+)-PulAR plasmid in our previous study. Escherichia coli DH5a was used as the host for cloning, and E. coli BL21(DE3) served as the host for the expression of the enzymes. Phanta Super-Fidelity DNA Polymerase and restriction enzyme Dpn I were purchased from Vazyme Biotech Co., Ltd (Nanjing, China). All other chemicals and reagents were obtained from standard commercial sources.

\subsection{Genomic Dna Extraction, Amplification And Bioinformatics Analysis}

The genomic DNA of Anoxybacillus sp. AR-29 was extracted using TIANamp Bacteria DNA Kit (Tiangen, Beijing, China). And the genomic DNA of Anoxybacillus sp. AR-29 was used as the template for the amplification of the pulAR-encoding gene, using forward primer 5'-GCGATATCATGTATGAGGTCTTTTCC-3' and reverse primer 5'-GCCTCGAGTTATATGTGATTTGCTTTTT-3' respectively. PuIAR gene was amplified 
by PCR according to the following protocol: denaturation at $95^{\circ} \mathrm{C}$ for $60 \mathrm{~s}, 20$ cycles of $\left(95^{\circ} \mathrm{C}, 30 \mathrm{~s} ; 55^{\circ} \mathrm{C}\right.$, $30 \mathrm{~s} ; 72^{\circ} \mathrm{C}, 90 \mathrm{~s}$ ), and a final extension at $72^{\circ} \mathrm{C}$ for $10 \mathrm{~min}$. The protein sequence and nucleotide sequence of PulAR were analyzed using BLASTp and BLASTn (http://www.ncbi.nlm.nih.gov/). The MW and pl of this enzyme were predicted by using the web server (http://web.expasy.org/compute_pi/).

\subsection{Cloning, Over-expression And Purification Of Pular}

The PCR products were double digested with the restriction enzymes EcoR V and Xho I and cloned into the pET-32a (+), which was also digested by the same restriction enzymes, yielding the recombined plasmid pET-32a (+)-PuIAR. For over-expression of PulAR in E. coli BL21(DE3), the recombinant plasmid was transformed into E. coli BL21(DE3). The transformant was picked into the tube with $5 \mathrm{~mL} L B$ medium containing $100 \mu \mathrm{g} / \mathrm{mL}$ ampicillin and cultivated at $37^{\circ} \mathrm{C}$ overnight. The overnight cultures were then transferred into pre-sterilized medium at $37^{\circ} \mathrm{C}$, grown for about $3 \mathrm{~h}$ until the OD at $600 \mathrm{~nm}$ was between 0.6 and 0.8 . The protein expression was then induced by adding IPTG at a final concentration of $0.5 \mathrm{mM}$ for $16 \mathrm{~h}$ at $16^{\circ} \mathrm{C}$. The cells were harvested by centrifugation at $8,000 \mathrm{~g}$ for $10 \mathrm{~min}$ at $4^{\circ} \mathrm{C}$ and resuspended in $20 \mathrm{~mL}$ of binding buffer $(20 \mathrm{mM}$ Tris- $\mathrm{HCl}, 250 \mathrm{mM} \mathrm{NaCl}, 20 \mathrm{mM}$ imidazole). The cell lysate was prepared by a French press operating at $4^{\circ} \mathrm{C}$, and then centrifuged at $8,000 \mathrm{~g}$ for $30 \mathrm{~min}$. The resultant soluble fraction was micro-filtrated, and loaded on a Ni-NTA column which was pre-equilibrated with the binding buffer. The target protein PulAR was eluted by a 20-250 mM imidazole gradient at a flow rate of $1 \mathrm{~mL} / \mathrm{min}$. The protein was pooled and dialysed with Buffer $\mathrm{C}(20 \mathrm{mM}$ Tris- $\mathrm{HCl}$ and $150 \mathrm{mM}$ $\mathrm{NaCl}, \mathrm{pH}$ 8.0). The purified protein was estimated by SDS-PAGE, and the concentration of the protein was determined according by the BCA protein assay kit.

\subsection{Characterization Of Wt-pular}

Pullulanase activity was measured in $500 \mu \mathrm{L}$ reaction mixtures that contained $50 \mu \mathrm{L}$ of pullulan $(0.5 \%)$, $400 \mu \mathrm{L}$ of sodium phosphate buffer $(100 \mathrm{mM}, \mathrm{pH} \mathrm{6.0)}$, and the appropriate amounts of the purified enzymes, and incubated at $60^{\circ} \mathrm{C}$ for $10 \mathrm{~min}$. One unit of pullulanase activity was defined as the amount of enzyme required to release $1 \mu \mathrm{mol}$ of reducing sugars per minute. Effects of $\mathrm{pH}$ on the purified PulAR were determined in $100 \mathrm{mM}$ buffer over $\mathrm{pH}$ 3.6-9, including sodium acetate buffer ( $\mathrm{pH}$ 3.6-5.8), sodium phosphate buffer ( $\mathrm{pH}$ 5.8-7.5) and Tris- $\mathrm{HCl}$ buffer ( $\mathrm{pH}$ 7.5-9.0). The optimal temperature of PulAR was measured at $45-95^{\circ} \mathrm{C}$ in $100 \mathrm{mM}$ sodium acetate buffer $(\mathrm{pH} 6.0)$.

The kinetic parameters of WT-PulAR were determined according to the method as previously described (Li et al., 2015), using pullulan at varying concentrations $(1.0,1.25,1.33,2.0,2.5,3.33$, and $5.0 \mathrm{mg} / \mathrm{mL})$ as substrate at $60^{\circ} \mathrm{C}$ for $10 \mathrm{~min}$ in $100 \mathrm{mM}$ buffer $(\mathrm{pH}$ 6.0). Experiments were conducted in triplicates. The Michaelis-Menten equation was fitted to the data points to determine $K_{\mathrm{M}}$ and $v_{\max }$ by nonlinear leastsquares regression analysis using Origin 8.5.

\subsection{Screening for mutation hotspots by a structure-guided consensus approach}


The protein sequence of PuIAR was aligned with the pullulanases from Anoxybacillus sp. 18-11 $\left(\mathrm{pH}_{\mathrm{opt}}\right.$ 6.0) (PulA) (Xu et al., 2014), Bacillus acidopullulyticus $\left(\mathrm{pH}_{\mathrm{opt}}\right.$ 5.0) (Bapul) (Turkenburg et al., 2009), and Bacillus naganoensis ( $\mathrm{pH}_{\mathrm{opt}}$ 4.5) (Bnpul) (Nie et al., 2013). The optimum temperature range of these pullulanases was between $55-65^{\circ} \mathrm{C}$. The putative structure of PulAR was obtained with the homologymodelling pipeline SWISS-MODEL server (http://swiss-model.expasy.org), using the structure of type I pullulanase (PDB ID: 3WDH) from Anoxybacillus sp. LM18-11 as the template. The structures were analyzed and visualized using PyMOL (http://www.pymol.org/). Totally, five residues (A365, T399, V401, Y491, and T504) different from the acidophilic pullulanases (Bapul and Bnpul) were selected for SDM. In addition, residue $\mathrm{H} 499$ was also chosen for SDM, inspired by the role of Y477 in PulA thermostability (Li et al. 2015).

\subsection{Construction Of The Mutants}

The PulAR gene was cloned into the pET-32a(+) plasmid, and the recombinant plasmid pET-32a(+)-PulAR was used as the template for mutation. The PCR was conducted as follows: $95^{\circ} \mathrm{C}$ for $5 \mathrm{~min}$, then 26 cycles $\left(95^{\circ} \mathrm{C}\right.$ for $30 \mathrm{~s}, 50^{\circ} \mathrm{C}$ for $30 \mathrm{~s}$, and $72^{\circ} \mathrm{C}$ for $8 \mathrm{~min}$ ), and final extension at $72^{\circ} \mathrm{C}$ for $10 \mathrm{~min}$. The PCR reaction system $(25 \mu \mathrm{L}$ ) consisted of $12.5 \mu \mathrm{L} 2 \times$ Phanta buffer, $0.5 \mu \mathrm{L}$ dNTP mixture (each at $10 \mathrm{mmol}$ $\left.\mathrm{L}^{-1}\right), 1 \mu \mathrm{L}$ forward primer $\left(10 \mu \mathrm{mol} \mathrm{L}^{-1}\right), 1 \mu \mathrm{L}$ reverse primer $\left(10 \mu \mathrm{mol} \mathrm{L}^{-1}\right), 1 \mu \mathrm{L}$ plasmid template $(50 \mathrm{ng})$, $8.5 \mu \mathrm{L}$ ultra-pure water, and $0.5 \mu \mathrm{L}$ DNA Polymerase $\left(1 \mathrm{U} \mathrm{L}^{-1}\right)$. The primers were listed in Table S1. The PCR products were then digested with Dpn I enzyme and transformed into E. coli BL21(DE3).

\subsection{Expression, Purification And Characterization Of Pular Mutants}

The expression, purification, and characterization of the PuIAR mutants were conducted according to the methods described above as 2.3 and 2.4. The purified protein was analyzed by SDS-PAGE (Figure S1).

\subsection{Structural And Md Simulation Analyses Of Pular}

Homology modeling of the PuIAR mutants was performed with the same approach as used for WT. YASARA software was used for molecular dynamics simulation (MD simulation). MD simulations were performed at $60^{\circ} \mathrm{C}$ and $\mathrm{pH} 5.0$ for $10 \mathrm{~ns}$. During the dynamic simulation, the force field was Amber 03 , the TIP3P model was used, and the concentration of $\mathrm{NaCl}$ was set at $0.9 \%$. After initial minimization through the steepest descent and simulated annealing, convergence was reached. The time step is $1 \mathrm{fs}$, and the track is saved every $100 \mathrm{ps}$. All independent MD simulations were repeated three times.

\section{Results And Discussion}




\subsection{Sequence analysis of PulAR encoding gene}

The pullulanase PulAR gene (GenBank accession number KY273924.1) has a putative translational start site GTG, is 2,259 bp long, has a $\mathrm{G}+\mathrm{C}$ content of $78.4 \%$, and encodes an enzyme with a predicted molecular mass of $85.0 \mathrm{kDa}$ with a theoretical pl of 5.49. The structure of PulAR was constructed based on the crystal structure of the pullulanase PulA from Anoxybacillus sp. LM18-11 (PDB ID 3WDH), with which it shares the identity $58.29 \%$ (Fig. 1A). The structure and protein sequence of type I pullulanase from Anoxybacillus sp. LM18-11 (PulA) (Xu et al. 2014) and that of PulAR were compared. For PulA, D413, E442, and D526 should be nucleophile, acid/base, and transition-state stabilizer, respectively. Accordingly, the corresponding residues D435, E464, and D554 of PulAR are deduced as the catalytic residues. Analysis of the protein sequence of PuIAR by NCBI BLASTp showed that it contains the YNWGYDP motif and four conserved regions (I-IV) (Figure S2), which are similar to those of type I pullulanases. No signal peptide was found in the pullulanase PuIAR through analysis by Signal $P$ (https://services.healthtech.dtu.dk/service.php?SignalP-4.1). Comparisons with the pullulanase sequences in the GenBank database, listed in Table 1, reveal that PuIAR shares 70.8\%, $60.2 \%, 58.29 \%$, $46.48 \%, 43.59 \%, 41.5 \%, 41.14 \%$ and $38.14 \%$ identity with the thermostable pullulanases from Bacillus stearothermophilus (Kuriki et al. 1990), Geobacillus thermoleovorans (Zouari Ayadi et al. 2008), Anoxybacillus sp. LM18-11 (Xu et al. 2014), Bacillus sp. CICIM 263 (Li et al. 2012), Anaerobranca gottschalkii (Bertoldo et al. 2004), Fervidobacterium pennivorans DSM 9078 (Bertoldo et al. 1999), Thermotoga neapolitana (Kang et al. 2011), and Caldicellulosiruptor saccharolyticus (Albertson et al. 1997), respectively.

Table 1

Comparison of optimum temperatures between bacterial type I pullulanases.

\begin{tabular}{|lllll|}
\hline Bacterial source & $\begin{array}{l}\text { Accession } \\
\text { number }\end{array}$ & $\begin{array}{l}\text { Optimum } \\
\text { temperature }\end{array}$ & $\begin{array}{l}\text { Similarity with } \\
\text { PulAR }\end{array}$ & Reference \\
\hline Bacillus stearothermophilus & 1808262A & $60^{\circ} \mathrm{C}$ & $70.8 \%$ & $\begin{array}{l}\text { Kuriki et al. } \\
1990\end{array}$ \\
\hline Geobacillus thermoleovorans & CAC85704.1 & $70^{\circ} \mathrm{C}$ & $60.2 \%$ & $\begin{array}{l}\text { Zouari Ayadi et } \\
\text { al. 2008 }\end{array}$ \\
\hline Anoxybacillus sp. LM18-11 & AEW23439.1 & $60^{\circ} \mathrm{C}$ & $58.3 \%$ & Xu et al. 2014 \\
\hline $\begin{array}{l}\text { Bacillus sp. CICIM 263 } \\
\text { Anaerobranca gottschalkii }\end{array}$ & AGA03915.1 & $70^{\circ} \mathrm{C}$ & $46.5 \%$ & Li et al. 2012 \\
\hline $\begin{array}{l}\text { Fervidobacterium } \\
\text { pennivorans DSM 9078 }\end{array}$ & AAD30387.1 & $80^{\circ} \mathrm{C}$ & $41.5 \%$ & $\begin{array}{l}\text { Bertoldo et al. } \\
2004\end{array}$ \\
\hline $\begin{array}{l}\text { Thermotoga neapolitana } \\
\text { Caldicellulosiruptor }\end{array}$ & ACN58254.1 & $80-70^{\circ} \mathrm{C}$ & $43.6 \%$ & 1999 \\
\hline \begin{tabular}{l} 
saccharolyticus \\
\hline
\end{tabular} & AAB06264.1 & active at $85^{\circ} \mathrm{C}$ & $38.1 \%$ & $\begin{array}{l}\text { Kang et al. } 2011 \\
\text { Albertson et al. }\end{array}$ \\
\hline
\end{tabular}




\subsection{Screening for mutation hotspots and generation of positive mutants}

To identify the critical residues responsible for catalytic activity and stability of PulAR, we compared the protein sequences and structures of neutrophilic type I pullulanases PuIA and PulAR with the acidophilic pullulanases, of which optimum conditions were at $50-60^{\circ} \mathrm{C}$ and $\mathrm{pH} 4.5-6.0$. Thus, the sequences of pullulanase from Bapul and Bnpul were selected to align with the neutrophilic type I pullulanases (Figure $1 \mathrm{a})$, and the difference in the amino acid residues among the above pullulanases within $8 \AA$ of the catalytic triad was explored (Figure 1b). Finally, six mutants A365V, T399S, V401T, V401C, Y491V, and T504V, were generated. Besides, the single mutant H499A was also constructed.

\subsection{Characterization Of Pular Mutants}

First, the pullulanase activities of seven mutants were assayed at $\mathrm{pH} 5.0$ and $\mathrm{pH} 6.0$, respectively, and the activity ratio of WT and its mutants at $\mathrm{pH} 5.0$ to that at $\mathrm{pH} 6.0\left(\mathrm{~A}_{\mathrm{pH} 5.0} / \mathrm{A}_{\mathrm{pH} 6.0}\right)$ were evaluated. As described in Table S2, $A_{p H 5.0} / A_{p H 6.0}$ of WT-PulAR and its mutants (A365V, T399S, V401T, V401C, Y491V, and T504V) were $0.20,0.49,0.12,0,0.75,0.19$, and 0.29 respectively. Therefore, we combined the positive mutations A365V, V401C, and T504V, and the mutation H499A, generating three combined mutants, PulAR-A365V-V401C, PulAR-A365V-V401C-T504V, and PulAR-A365V-V401C-T504V-H499A.

We characterized the three combined mutants PulAR-A365V-V401C, PulAR-A365V-V401C-T504V, and PulAR-A365V-V401C-T504V-H499A, as well as two single mutants PulAR-A365V and PulAR-V401C. As shown in Figure 2, the optimum temperature $\left(T_{\text {opt }}\right)$ of PulAR was $55^{\circ} \mathrm{C}$, and these of the mutants PulARA365V, PulAR-V401C, PulAR-A365V-V401C, PulAR-A365V-V401C-T504V, and PulAR-A365V-V401C-T504VH499A were $55,55,60,60,60$, and $65^{\circ} \mathrm{C}$, respectively. Compared with WT, the $T_{\text {opt }}$ of the mutant PulARA365V-V401C-T504V-H499A was increased by $10^{\circ} \mathrm{C}$. In addition, at $60^{\circ} \mathrm{C}$ and $\mathrm{pH} 6.0$, the specific activities of WT and its mutants PulAR-A365V, PulAR-V401C, PulAR-A365V-V401C, PulAR-A365V-V401CT504V, and PulAR-V401C-T504V-H499A were 24.4, 37.8, 43.3, 48.9, 68.9, and $87.8 \mathrm{U} / \mathrm{mg}$. The optimum pH of PulAR-A365V, PulAR-V401C, PulAR-A365V-V401C, and PulAR-A365V-V401C-T504V was 6.0, which was similar to that of the WT. At $60^{\circ} \mathrm{C}$ and $\mathrm{pH} 5.0$, the specific activities of PulAR and its mutants PulARA365V, PulAR-V401C, PulAR-A365V-V401C, PulAR-A365V-V401C-T504V, and PulAR-A365V-V401C-T504V$\mathrm{H} 499 \mathrm{~A}$ were $4.4,10.0,14.4,32.2$, and $40.0 \mathrm{U} / \mathrm{mg}$, respectively. Among them, the specific activity of the quadruple mutant PulAR-A365V-V401C-T504V-H499A was 8.1-fold higher than that of WT.

To evaluate the thermostability, the enzymes were incubated at $60^{\circ} \mathrm{C}$ and $\mathrm{pH} 6.0$, and the residual activities were assayed after varying incubation times. As shown in Table 2, all the mutants PulAR-A365V, PulAR-V401C, PulAR-A365V-V401C, PulAR-A365V-V401C-T504V, and PulAR-A365V-V401C-T504V-H499A displayed enlarged half-lives. At 60 and $65^{\circ} \mathrm{C}$, the half-lives $\left(t_{1 / 2}\right)$ of PulAR were only 4.8 and $2.5 \mathrm{~h}$, respectively, whereas those of the quadruple mutant were 17.5 and $10.3 \mathrm{~h}$, which were 2.65 and 3.12 -fold higher than those of PuIAR. The stabilities of PuIAR under the acidic conditions ( $\mathrm{pH} 4.5$ and 5.0) were also significantly enhanced. The half-lives of PuIAR were 5.4 and $6.1 \mathrm{~h}$ at pH 4.5 and 5.0, respectively, 
whereas those of the quadruple mutant PulAR-A365V-V401C-T504V-H499A displayed longer half-lives of 13.9 and $17.3 \mathrm{~h}$, respectively (Table 3 ). The structures of PulAR and its mutants were modeled to investigate the mechanisms of the enhanced thermostability and pH stability. A365 is buried in the internal of the protein. As shown in Figure 3, the mutation A365V introduces two extra hydrophobic interactions F432-V365 and F434-V365 while maintaining the two hydrogen bonds V365-R433 and D435V365. For the mutation V401C, the residue Cys also forms a hydrogen bond with the residue T399 and a tighter hydrophobic interaction with $\mathrm{H} 369$ like the residue V401. Because of the mutation V401C is located on the protein surface, the stability might be enhanced by the hydrogen bonds formed between C401 and solvent water molecules. Similar to the mutation Y477A in our previous report, the solvent accessibility of the residue at the position 499 was reduced from 29.9 to 2.4, making the protein structure of PulAR more compact (Li et al. 2015). Replacing T504 with Val possessing an extra $\mathrm{CH}_{3}$ group reinforces the hydrophobic protein interior, leading to enhancement of the thermostability and $\mathrm{pH}$ stability(Tai et al. 2011).

Table 2

Half-lives of WT-PulAR and its variants at 60 and $65^{\circ} \mathrm{C}$.

\begin{tabular}{|lllll|}
\hline Mutant & \multicolumn{3}{c|}{$60^{\circ} \mathrm{C}$} & \multicolumn{2}{c|}{${ }^{\circ} \mathrm{C}$} \\
\cline { 2 - 5 } & $\boldsymbol{k}_{d}(1 / \mathrm{h})$ & $\boldsymbol{t}_{1 / 2}(\mathrm{~h})$ & $\boldsymbol{k}_{\boldsymbol{d}}(\mathbf{1} / \mathrm{h})$ & $\boldsymbol{t}_{1 / 2}(\mathrm{~h})$ \\
\hline WT-PulAR & 0.14 & $4.8 \pm 0.2$ & 0.28 & $2.5 \pm 0.1$ \\
\hline PulAR-A365V & 0.12 & $5.9 \pm 0.5$ & 0.17 & $4.1 \pm 0.2$ \\
\hline PulAR-V401C & 0.12 & $6.0 \pm 0.1$ & 0.17 & $4.1 \pm 0.1$ \\
\hline PulAR-A365V-V401C & 0.07 & $9.9 \pm 0.2$ & 0.10 & $6.7 \pm 0.4$ \\
\hline PulAR-A365V-V401C-T504V & 0.05 & $13.2 \pm 0.1$ & 0.08 & $9.2 \pm 0.2$ \\
\hline PulAR-A365V-V401C-T504V-H499A & 0.04 & $17.5 \pm 0.1$ & 0.07 & $10.3 \pm 0.3$ \\
\hline
\end{tabular}

Table 3

Half-lives of WT-PulAR and its variants at $\mathrm{pH} 4.5$ and 5.0 .

\begin{tabular}{|lllll|}
\hline Mutant & $\mathrm{pH} 4.5$ & \multicolumn{3}{c|}{$\mathrm{pH} 5.0$} \\
\cline { 2 - 5 } & $\boldsymbol{k}_{\boldsymbol{d}}(\mathbf{1} / \mathrm{h})$ & $\boldsymbol{t}_{1 / 2}(\mathrm{~h})$ & $\boldsymbol{k}_{\boldsymbol{d}}(\mathbf{1} / \mathrm{h})$ & $\boldsymbol{t}_{1 / 2}(\mathrm{~h})$ \\
\hline WT-PulAR & 0.13 & $5.4 \pm 0.3$ & 0.11 & $6.1 \pm 0.5$ \\
\hline PulAR-A365V & 0.10 & $7.0 \pm 0.4$ & 0.08 & $8.5 \pm 1.4$ \\
\hline PulAR-V401C & 0.10 & $7.1 \pm 0.6$ & 0.08 & $8.4 \pm 0.3$ \\
\hline PulAR-A365V-V401C & 0.07 & $9.4 \pm 0.3$ & 0.06 & $10.8 \pm 0.2$ \\
\hline PulAR-A365V-V401C-T504V & 0.06 & $11.1 \pm 0.4$ & 0.05 & $13.6 \pm 1.0$ \\
\hline PulAR-A365V-V401C-T504V-H499A & 0.05 & $13.9 \pm 1.2$ & 0.04 & $17.3 \pm 1.2$ \\
\hline
\end{tabular}




\subsection{Kinetic Parameters Of Wt-pular And Its Mutants}

WT-PulAR and its mutants were subjected to kinetic analysis at $60^{\circ} \mathrm{C}, \mathrm{pH} 5.0$ and 6.0 , respectively. Compared with WT, at $\mathrm{pH} 6.0,60^{\circ} \mathrm{C}$, the $K_{M}$ values of PulAR-A365V, PulAR-V401C, PulAR-A365V-V401C, PulAR-A365V-V401C-T504V, and PulAR-A365V-V401C-T504V-H499A decreased by 7.3\%, 7.3\%, 24.4\%, $33.5 \%$, and $53.0 \%$, respectively, while the $k_{\text {cat }}$ values increased by $39.1 \%, 54.3 \%, 168.9 \%, 193.7 \%$, and $254.3 \%$, respectively (Table 4). In addition, at pH 5.0, $60^{\circ} \mathrm{C}$, the $K_{M}$ values of PulAR-A365V, PulAR-V401C, PulAR-A365V-V401C, PulAR-A365V-V401C-T504V, and PulAR-A365V-V401C-T504V-H499A decreased by $15.2 \%, 19.3 \%, 31.7 \%, 43.7 \%, 68.5 \%$, respectively, while the $k_{\text {cat }}$ values increased by $37.7 \%, 45.7 \%, 154.8 \%$ $196.7 \%$, and $230.7 \%$ (Table 5). Resultantly, the catalytic efficiencies $\left(k_{\text {cat }} / K_{M}\right)$ of the quadruple mutant PulAR-A365V-V401C-T504V-H499A were 6.6 and 9.6-fold higher than those of PulAR, at pH 6.0 and 5.0, respectively. The catalytic efficiency of PulAR was enhanced by mutations identified by sequence alignment of the acidophilic pullulanase and neutrophilic pullulanase, and we further analyzed the roles of A365, V401, T504, and H499 in the structure-function relationship. The residues A365, V401, T504, and H499 lining the catalytic pocket are shown in Figure 1(b). They are located within $8 \AA$ of the catalytic residues D435, E464, and D554. All the single mutations A365V, V401C, T504V, H499 and the superposition of mutations tend to confer increased flexibility of the active sites, therefore raising catalytic efficiency.

Table 4

Catalytic efficiencies of WT-PulAR and its mutants at $60^{\circ} \mathrm{C}$ and $\mathrm{pH} 6.0$.

\begin{tabular}{|lllll|}
\hline Mutant & $\begin{array}{l}\boldsymbol{v}_{\max }(\mu \mathrm{mol} \mathrm{min} \\
\left.\mathrm{mg}^{-1}\right)\end{array}$ & $\begin{array}{l}\boldsymbol{K}_{\mathrm{M}}(\mathbf{m g} \\
\left.\mathrm{mL}^{-1}\right)\end{array}$ & $\begin{array}{l}\boldsymbol{k}_{\text {cat }} \\
\left(\mathbf{s}^{-1}\right)\end{array}$ & $\begin{array}{l}\boldsymbol{k}_{\text {cat }} / \boldsymbol{K}_{\mathrm{M}}(\mathrm{mL} \\
\left.\mathrm{mg}^{-1} \mathbf{s}^{-1}\right)\end{array}$ \\
\hline WT-PulAR & $31.6 \pm 1.2$ & $1.64 \pm 0.20$ & 52.7 & 32.1 \\
\hline PulAR-A365V & $44.0 \pm 2.3$ & $1.52 \pm 0.12$ & 73.3 & 48.2 \\
\hline PulAR-V401C & $48.8 \pm 1.6$ & $1.52 \pm 0.50$ & 81.3 & 54.2 \\
\hline PulAR-A365V-V401C & $85.0 \pm 2.5$ & $1.24 \pm 0.32$ & 141.7 & 114.3 \\
\hline PulAR-A365V-V401C-T504V & $92.9 \pm 2.0$ & $1.09 \pm 0.11$ & 154.8 & 142.0 \\
\hline $\begin{array}{l}\text { PulAR-A365V-V401C-T504V- } \\
\text { H499A }\end{array}$ & $112.0 \pm 3.1$ & $0.77 \pm 0.15$ & 186.7 & 242.5 \\
\hline
\end{tabular}


Table 5

Catalytic efficiencies of WT-PulAR and its mutants at $60^{\circ} \mathrm{C}$ and $\mathrm{pH} 5.0$.

\begin{tabular}{|lllll|}
\hline Mutant & $\begin{array}{l}\boldsymbol{v}_{\max }(\mu \mathrm{mol} \mathrm{min} \\
\left.\mathrm{mg}^{-1}\right)\end{array}$ & $\begin{array}{l}K_{\mathrm{M}}(\mathrm{mg} \\
\left.\mathrm{mL}^{-1}\right)\end{array}$ & $\begin{array}{l}k_{\text {cat }} \\
\left(\mathbf{s}^{-1}\right)\end{array}$ & $\begin{array}{l}k_{\mathrm{cat}} / K_{\mathrm{M}}(\mathrm{mL} \\
\left.\mathrm{mg}^{-1} \mathbf{s}^{-1}\right)\end{array}$ \\
\hline WT-PulAR & $25.6 \pm 1.1$ & $4.67 \pm 0.12$ & 42.7 & 9.1 \\
\hline PulAR-A365V & $35.3 \pm 0.3$ & $3.96 \pm 0.13$ & 58.8 & 14.8 \\
\hline PulAR-V401C & $37.3 \pm 0.5$ & $3.77 \pm 0.20$ & 62.2 & 16.8 \\
\hline PulAR-A365V-V401C & $65.3 \pm 1.2$ & $3.19 \pm 0.50$ & 108.8 & 34.1 \\
\hline PulAR-A365V-V401C-T504V & $76.0 \pm 2.3$ & $2.63 \pm 0.28$ & 126.7 & 48.2 \\
\hline $\begin{array}{l}\text { PulAR-A365V-V401C-T504V- } \\
\text { H499A }\end{array}$ & $84.7 \pm 1.6$ & $1.47 \pm 0.05$ & 141.2 & 96.1 \\
\hline
\end{tabular}

To further investigate the mechanism of the PulAR mutant against high temperature and acidic $\mathrm{pH}, \mathrm{MD}$ simulation analysis of PulAR and the quadruple mutant AR-A365V-V401C-T504V-H499A was conducted. As shown in Figure 4, during the initial $6 \mathrm{~ns}$ for simulation, both the structures of PulAR and quadruple mutant AR-A365V-V401C-T504V-H499A are unstable. The entire protein conformation of the quadruple mutant became more stable than PuIAR after 6 ns simulation time, which is consistent with stability enhancement under the thermophilic and acidic conditions.

In this work, we identified the active sites lining the catalytic pocket of PulAR by using a structure-guided consensus approach. SDM yielded four mutations A365V, V401C, T504V, and H499A, which showed beneficial effects on thermostability and acid resistance. In addition, the catalytic efficiencies of all the mutants were also significantly enhanced. Structural comparison indicated that increased internal hydrophobic interactions and the reduced solvent accessibility surface area are the main reasons for thermostability and acid resistance enhancement. In conclusion, it was proved that such a structureguided consensus approach helps identify the critical residues for the improved catalytic performance of PulAR under thermophilic and acidic conditions, and the improved pullulanase exhibited great potential in the production of high-purity maltose syrup and other related starch processing industry.

\section{Declarations}

\section{Ethics approval and consent to participate}

Not applicable.

\section{Consent for publication}

All the authors have read and approved to submit it to Bioresources and Bioprocessing.

\section{Availability of data and materials}


The data and the materials are all available in this article and additional document file.

\section{Competing interests}

The authors declare no competing financial interests.

\section{Funding}

This research was financially supported by National Natural Science Foundation of China (31801466, 22178318).

\section{Authors' contributions}

YJW conceived of the study. SFL performed the experiment. SFL and SYX statistically analyzed the data, and collected the data. YJW and SYX drafted the manuscript. YGZ revised the manuscript.

\section{Acknowledgements}

We gratefully acknowledge Professor Hui Song from Tianjin Institute of Industrial Biotechnology, Chinese Academy of Sciences, for generously providing Anoxybacillus sp. AR-29.

\section{References}

1. Albertson GD, McHale RH, Gibbs MD, Bergquist PL (1997) Cloning and sequence of a type I pullulanase from an extremely thermophilic anaerobic bacterium, Caldicellulosiruptor saccharolyticus. Biochimica et Biophysica Acta (BBA) - Gene Structure and Expression, 1354(1), 3539

2. Böttcher D, Bornscheuer UT (2010) Protein engineering of microbial enzymes. Current Opinion in Microbiology, 13(3), 274-282

3. Bertoldo C, Antranikian G (2002) Starch-hydrolyzing enzymes from thermophilic archaea and bacteria. Curr Opin Chem Biol, 6(2), 151-160

4. Bertoldo C, Armbrecht M, Becker F, Schäfer T, Antranikian G, Liebl W (2004) Cloning, sequencing, and characterization of a heat- and alkali-stable type I pullulanase from Anaerobranca gottschalkii. Appl Environ Microbiol, 70(6), 3407-3416

5. Bertoldo C, Duffner F, Jorgensen PL, Antranikian, G (1999) Pullulanase type I from Fervidobacterium pennavorans Ven5: cloning, sequencing, and expression of the gene and biochemical characterization of the recombinant enzyme. Appl Environ Microbiol, 65(5), 2084-2091

6. Bi J, Chen S, Zhao X, Nie Y, Xu Y (2020) Computation-aided engineering of starch-debranching pullulanase from Bacillus thermoleovorans for enhanced thermostability. Appl Microbiol Biotechnol, 104(17), 7551-7562

7. Chen A, Xu T, Ge Y, Wang L, Tang W, Li S (2019) Hydrogen-bond-based protein engineering for the acidic adaptation of Bacillus acidopullulyticus pullulanase. Enzyme and Microbial Technology, 124, 
$79-83$

8. Duan X, Chen J, Wu J (2013) Improving the thermostability and catalytic efficiency of Bacillus deramificans pullulanase by site-directed mutagenesis. Appl Environ Microbiol, 79(13), 4072-4077

9. Hii SL, Tan JS, Ling TC, Ariff AB (2012) Pullulanase: role in starch hydrolysis and potential industrial applications. Enzyme Res, 2012, 921362

10. Kahar UM, Ng CL, Chan KG, Goh KM (2016) Characterization of a type I pullulanase from Anoxybacillus sp. SK3-4 reveals an unusual substrate hydrolysis. Appl Microbiol Biotechnol, 100(14), 6291-6307

11. Kang J, Park KM, Choi KH, Park CS, Kim GE, Kim D, Cha J (2011) Molecular cloning and biochemical characterization of a heat-stable type I pullulanase from Thermotoga neapolitana. Enzyme and Microbial Technology, 48(3), 260-266

12. Kuriki T, Park JH, Imanaka T (1990) Characteristics of thermostable pullulanase from Bacillus stearothermophilus and the nucleotide sequence of the gene. Journal of Fermentation and Bioengineering, 69(4), 204-210

13. Li L, Dong F, Lin L, He D, Wei W, Wei D (2018) N-terminal domain truncation and domain insertionbased engineering of a novel thermostable type I pullulanase from Geobacillus thermocatenulatus. Journal of Agricultural and Food Chemistry, 66(41), 10788-10798

14. Li SF, Xu JY, Bao YJ, Zheng HC, Song H (2015) Structure and sequence analysis-based engineering of pullulanase from Anoxybacillus sp. LM18-11 for improved thermostability. J Biotechnol, 210, 8-14

15. Li Y, Zhang L, Niu D, Wang Z, Shi G (2012) Cloning, expression, characterization, and biocatalytic investigation of a novel bacilli thermostable type I pullulanase from Bacillus sp. CICIM 263. J Agric Food Chem, 60(44), 11164-11172

16. Lin Q, Xiao H, Liu GQ, Liu Z, Li L, Yu F (2013) Production of maltose syrup by enzymatic conversion of rice starch. Food and Bioprocess Technology, 6(1), 242-248

17. Masahiro N, Yukari H, Koichi K, Yoshibumi I, Kazuaki Kato (1992) Manufacturing method of high purity maltose and its reduced product [P]. United States Patent, US19890425714

18. Nie Y, Yan W, Xu Y, Chen WB, Mu XQ, Wang X, Xiao R (2013) High-level expression of Bacillus naganoensis pullulanase from recombinant Escherichia coli with auto-induction: effect of lac operator. PLoS One, 8(10), e78416

19. Pang B, Zhou L, Cui W, Liu Z, Zhou S, Xu J, Zhou Z (2019) A hyperthermostable type II pullulanase from a deep-sea microorganism Pyrococcus yayanosii CH1. J Agric Food Chem, 67(34), 9611-9617

20. Tai H, Irie K, Mikami SI, Yamamoto Y(2011) Enhancement of the thermostability of hydrogenobacter thermophilus Cytochrome c552 through introduction of an extra methylene group into its hydrophobic protein interior. Biochemistry, 50(15), 3161-3169

21. Turkenburg JP, Brzozowski AM, Svendsen A, Borchert TV, Davies GJ, Wilson KS (2009) Structure of a pullulanase from Bacillus acidopullulyticus. Proteins, 76(2), 516-519 
22. Wang QY, Xie NZ, Du QS, Qin Y, Li JX, Meng JZ, Huang RB (2017) Active hydrogen bond network (AHBN) and applications for improvement of thermal stability and $\mathrm{pH}$-sensitivity of pullulanase from Bacillus naganoensis. PLoS One, 12(1), e0169080

23. Wei W, Ma J, Chen SQ, Cai XH, Wei DZ (2015) A novel cold-adapted type I pullulanase of Paenibacillus polymyxa Nws-pp2: in vivo functional expression and biochemical characterization of glucans hydrolyzates analysis. BMC Biotechnol, 15, 96

24. Xu J, Ren F, Huang CH, Zheng Y, Zhen J, Sun H, Ko TP, He M, Chen CC, Chan HC, Guo, R.T., Song, H., $\mathrm{Ma}, \mathrm{Y}$ (2014) Functional and structural studies of pullulanase from Anoxybacillus sp. LM18-11. Proteins, 82(9), 1685-1693

25. Yang S, Yan Q, Bao Q, Liu J, Jiang Z (2017) Expression and biochemical characterization of a novel type I pullulanase from Bacillus megaterium. Biotechnol Lett, 39(3), 397-405.

26. Yang Y, Zhu Y, Obaroakpo JU, Zhang S, Lu J, Yang L, Ni D, Pang X, Lv J (2020) Identification of a novel type I pullulanase from Fervidobacterium nodosum Rt17-B1, with high thermostability and suitable optimal pH. International Journal of Biological Macromolecules, 143, 424-433.

27. Zeng Y, Xu J, Fu X, Tan M, Liu F, Zheng H., Song, H (2019) Effects of different carbohydrate-binding modules on the enzymatic properties of pullulanase. Int J Biol Macromol, 137, 973-981.

28. Zhang SY, Guo ZW, Wu XL, Ou XY, Zong MH, Lou WY (2020) Recombinant expression and characterization of a novel cold-adapted type I pullulanase for efficient amylopectin hydrolysis. Journal of Biotechnology, 313, 39-47.

29. Zouari Ayadi D, Ben Ali M, Jemli S, Ben Mabrouk S, Mezghani M, Ben Messaoud E, Bejar S (2008) Heterologous expression, secretion and characterization of the Geobacillus thermoleovorans US105 type I pullulanase. Appl Microbiol Biotechnol, 78(3), 473-81.

\section{Figures}

\section{Figure 1}

(a) Sequence alignment of PuIAR with Bacillus acidopullulyticus pullulanase (Bapul) and Bacillus naganoensis pullulanase (Bnpul). (b) Mutation hotspots A365, T399, V401, Y491, and T504.

\section{Figure 2}

Temperature (a) and pH (b) optima of WT-PulAR and its mutants. 


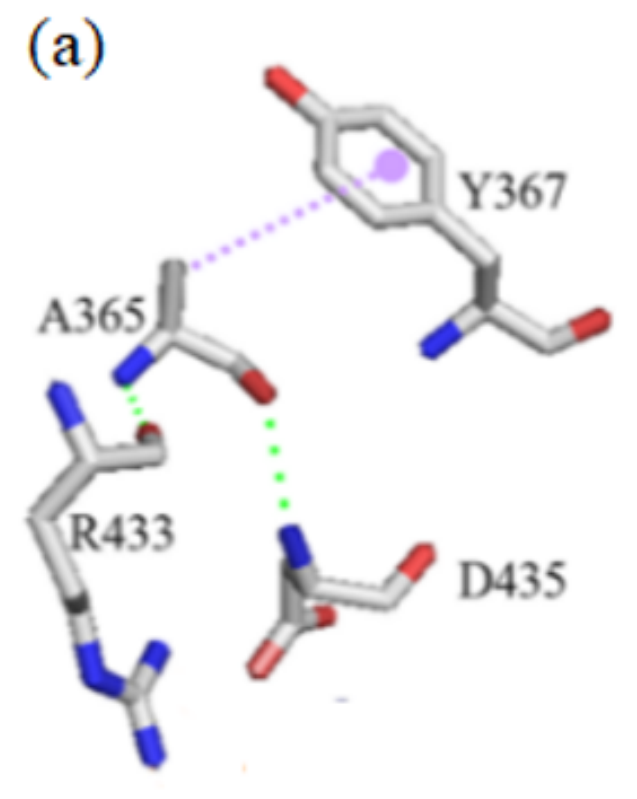

(b)

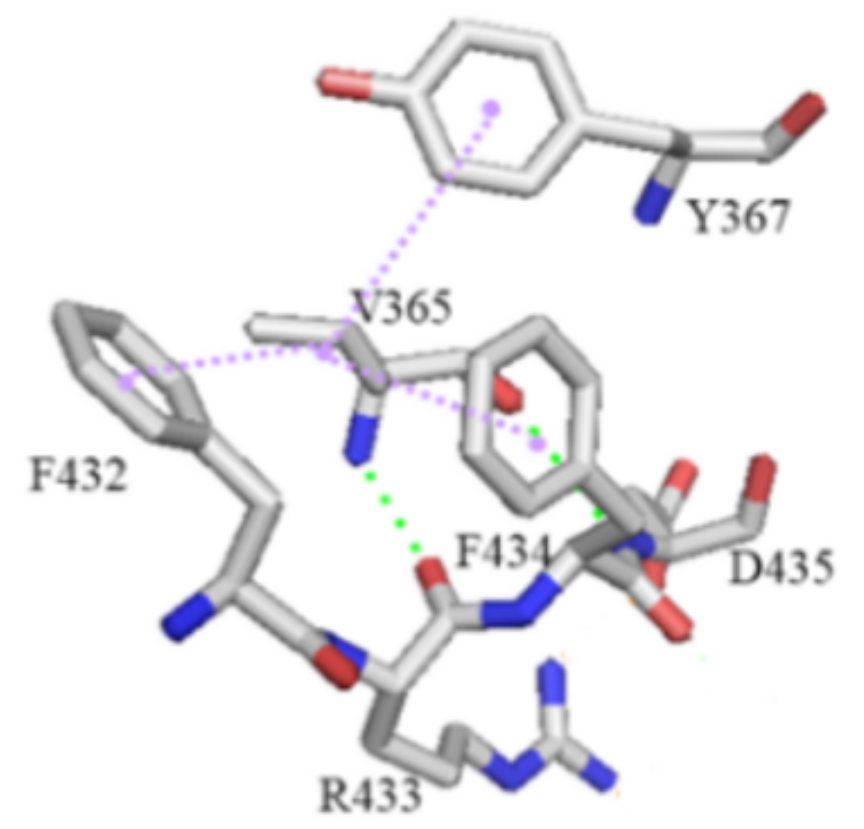

Figure 3

Structural analysis of PulAR before (a) and after (b) mutation A365V.

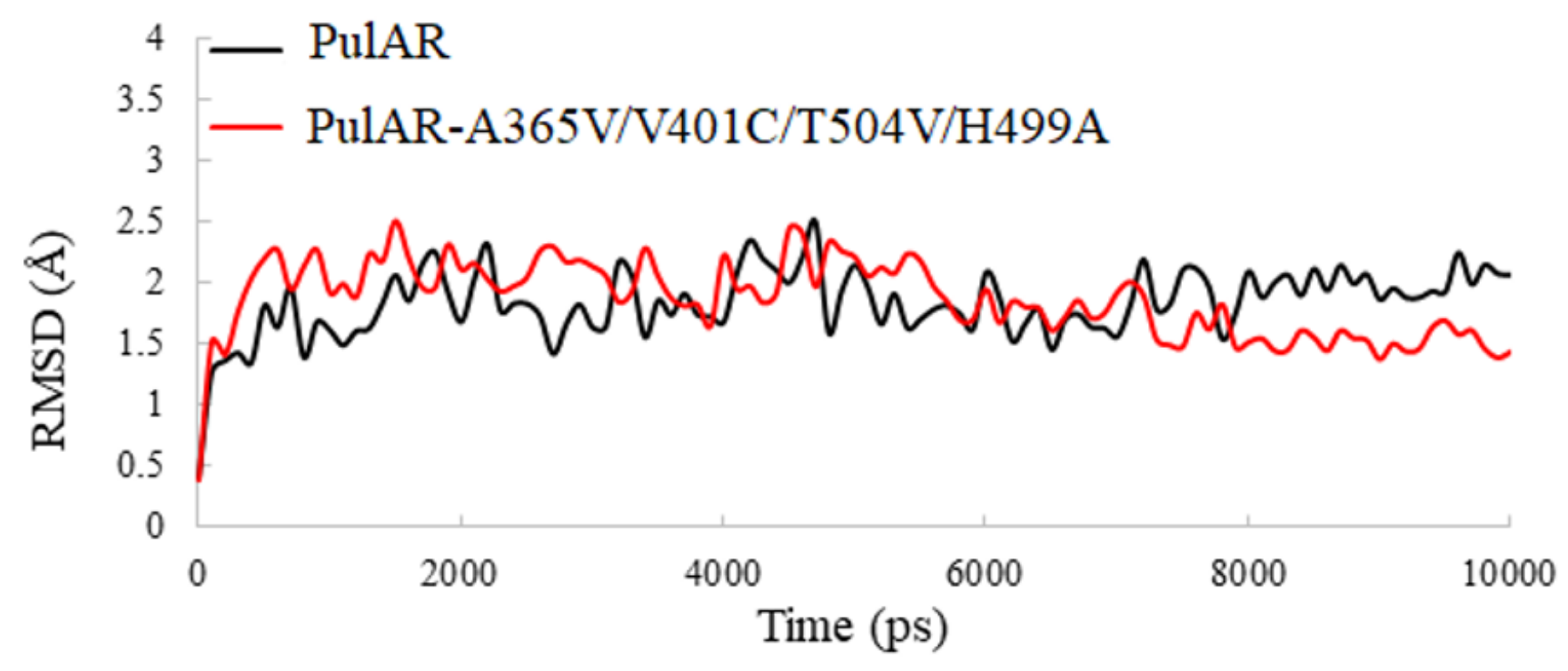

Figure 4

MD simulation analysis of WT-PulAR and its quadruple mutant PulAR-A365V-V401C-T504V-H499A. 


\section{Supplementary Files}

This is a list of supplementary files associated with this preprint. Click to download.

- Graphicabstract.jpg

- Surporrtinginformation.docx 